\title{
Study on the Phosphorus Accumulation Characteristics of Penicillium sp.JB201015
}

\author{
Jingyang Meng ${ }^{1, a}$,Jones Feyisike Gbolayori ${ }^{1, b}$, Wei Wang ${ }^{1, \mathrm{c}}$, Juntao Cui $^{*}$ \\ 1JILIN Agriculture University Xincheng Street 2888

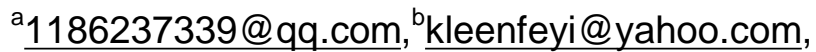 \\ c1252675242@qq.com, ${ }^{*}$ cuijuntao2005@163.com
}

Key words: Phosphorus accumulating organism ,fungi,polyphosphates,penicillium,

Abstract.Phosphorus resources are non-renewable and difficult to replace natural resources, but also play an important role in the development of strategic resources in the world. However, this element which was once considered to be extremely rich in nature will become a scarce resource in the near future.This experiment was carried out by the laboratory to provide Phosphorus accumulating organism strains, identified as the fungus penicillium $s p$. The results showed : (1) the biomass of penicillium $s p$. and its phosphorus uptake increased with the prolongation of culture time in the simulated sewage. The dry weight and phosphorus uptake were stable at the 8th day, which were $0.91 \mathrm{~g}$ and $16.89 \mathrm{mg} \cdot \mathrm{L}^{-1}$, respectively. The phosphorus uptake rate reached $16.89 \mathrm{mg} \cdot \mathrm{L}^{-1}$ and the rate of phosphorus accumulation was $84 \%$;(2) the effect of different forms of inorganic phosphorus on the strain was different. Among them, the effect of calcium and phosphorus was the highest, and the dry weight of strain was reached $14.3 \mathrm{~g} \cdot \mathrm{L}^{-1}$ after 10 days, and the amount of phosphorus reached $88.98 \mathrm{mg} \cdot \mathrm{L}^{-1}$.In addition, the results also showed that the use capacity of strain JB201015 for different forms of inorganic phosphorus was related to the amount of phosphorus and the strain of Penicillium sp.JB201015 could grow rapidly not only in simulated waste water, but also showed good ability of Phosphorus accumulating organism, which indicated that the strain had good application prospect in phosphorus recovery of waste water.

\section{Introduction}

Phosphate resources are non-renewable and difficult to replace natural resources, but also play an important role in the development of strategic resources in the world ${ }^{[1,2]}$. since the last century 80 's to be precise, many foreign countries have carried out research work from sewage and waste water recycling of phosphorus, and the development of a different process of phosphorus recovery from waste water and activated sludge ${ }^{[3,4]}$, respectively. while China's related research started late $^{[5,6]}$.

Phosphorus accumulating organisms play an important role in biological phosphorus removal and phosphorus recovery in waste water ${ }^{[7,8]}$. The past research mainly focused on phosphorus bacteria and the study of phosphorus accumulating fungi as an important member of the PAOs relevant is rarely reported ${ }^{[9]}$. In this study, a highly effective Penicillium sp.was used as a research object to study its ability of phosphorus accumulation and its main influencing factors in simulated waste water with a view to providing phosphorus for the recovery of phosphorus from waste water by using phosphate-solubilizing fungi new research ideas, methods and data reference.

\section{Materials and methods}

\section{Test materials}

Test strains:Penicillium sp.JB201015, it was deposited in the General Microbiological Center of China Microbial Culture Collection, CGMCC No.7919 
Test simulation of the composition and content of sewage substances

Sodium acetate $50 \mathrm{mg} \cdot \mathrm{L}^{-1}$, COD $300 \mathrm{mg} \cdot \mathrm{L}^{-1}$, dipotassium hydrogen phosphate $200.0 \mathrm{mg} \cdot \mathrm{L}^{-1}$, ammonium chloride $190.0 \mathrm{mg} \cdot \mathrm{L}^{-1}$, peptone $48.0 \mathrm{mg} \cdot \mathrm{L}^{-1}$, magnesium sulfate $171.0 \mathrm{mg} \cdot \mathrm{L}^{-1}$, calcium chloride $79.5 \mathrm{mg} /$ Liquid concentration $1 \mathrm{~g} / \mathrm{L}$.And add nutrient composition to it.

\section{Experimental design}

Phosphorus accumulating capacity of Penicillium sp.JB201015 strains

$10 \mathrm{ml}$ of polyphosphate suspension was inoculated into $100 \mathrm{~mL}$ simulated sewage, cultured at a culture temperature of $25^{\circ} \mathrm{C}$ and a rotation speed of 160rpm for 10 days, and the rate of Phosphorus accumulating organism was measured every 24 hours.

Effects of Different Carbon Sources,Nitrogen Sources and Phosphorus Sources on Phosphorus Accumulation Ability of Penicillium sp.JB201015

The liquid volume of $100 / 250 \mathrm{~mL}$, in the simulated sewage addition of $1 \%(\mathrm{~m} / \mathrm{V})$.Carbon Sources:glucose,fructose,maltose,Sodium Propionate,sodium acetate ; Nitrogen Sources: ammonium sulfate, ammonium nitrate, potassium nitrate, sodium nitrate and peptone ; phosphorus sources:Calcium phosphate, aluminium phosphate, ferric phosphate and phosphorus ore powder were used as the sole $\left(5 \mathrm{~g} \cdot \mathrm{L}^{-1}\right)$, Respectively.After 10 days of incubation, the available phosphorus and the dry weight of the cells in the solution were measured.1.3. Research methods

Determination of $\mathrm{PO}_{4}{ }^{3}-\mathrm{P}$ concentration in simulated sewage solution:molybdenum antimony anti-spectrophotometric method.

Determination of bacterial phosphorus concentration: Yuexi Zhou (1993).

phosphorus accumulating fungi, phosphorus structure,surface morphology and component analysis method

Using Hitachi desktop electron microscope TM3030Plus scanning electron microscope.The cells were taken out in the liquid culture, and freeze-dried in vacuum. The morphology of the mycelium was observed by electron microscopy.

The data were analyzed by 16.0 SPSS statistical software and Excel for variance

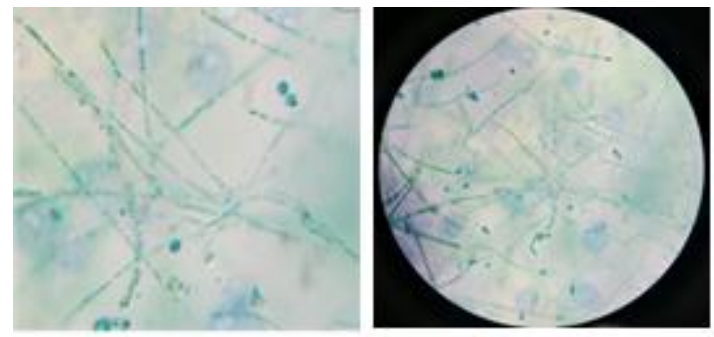

Figure 1. Hyphae under microscope (x 1000) left phosphorus, right phosphorus release

\section{Results and Analysis}

Phosphorus Accumulation Ability of Phosphorus Phosphorus Penicillium sp.JB201015 Strain

Under the aerobic condition, the phosphorus in the waste water will be absorbed into the cell cells and the heterogeneous particles will be formed. The phosphorus will be stored in the cells in the form of poly (phosphate) in the cell.

Under anaerobic condition, Polyphosphate hydrolysis, release of energy and phosphoric acid $\mathrm{H}_{3} \mathrm{PO}_{4}$ is a common characteristic of phosphorus accumulation. The results showed that the Penicillium sp. JB201015 strain had the characteristics of typical phosphorus accumulating fungi, which had excess phosphorus uptake under aerobic conditions and released phosphorus under anaerobic conditions (Fig. 1 and Fig. 2). The results showed that the biomass and phosphorus uptake increased with the prolongation of culture time in the simulated sewage (Fig. 3). The dry weight and phosphorus uptake were stable at the 8th day, which were $0.91 \mathrm{~g}$ and $16.89 \mathrm{mg} \cdot \mathrm{L}^{-1}$, respectively. The phosphorus uptake rate reached $16.89 \mathrm{mg} \cdot \mathrm{L}^{-1}$ and the rate of Phosphorus accumulating organism was $84 \%$. The results showed that the strain of Penicillium sp.JB201015 could not only grow rapidly in simulated waste water, but also showed good ability of Phosphorus 
accumulating organism, which indicated that the strain had good application prospect in phosphorus recovery of waste water.

Analysis of Surface Morphology and Composition Elements of Phosphorus accumulating fungi

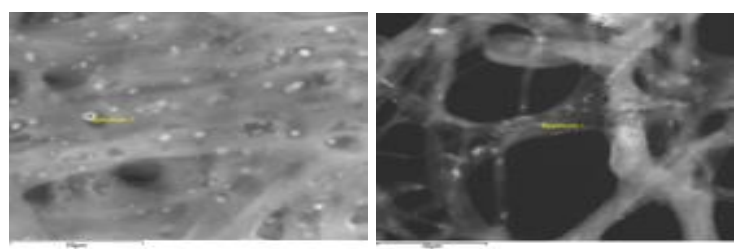

Figure 2 Electron microscopic scanning of hyphae and different staining $(\times 5000)$

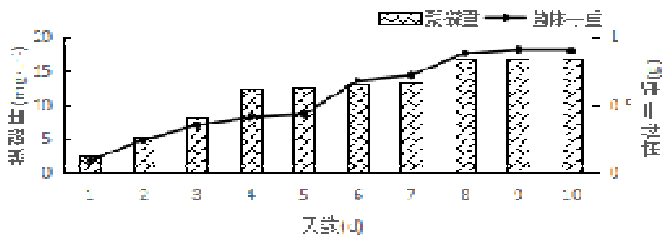

Figure 3: Variation of phosphorus uptake and cell drying in simulated waste water by phosphorus

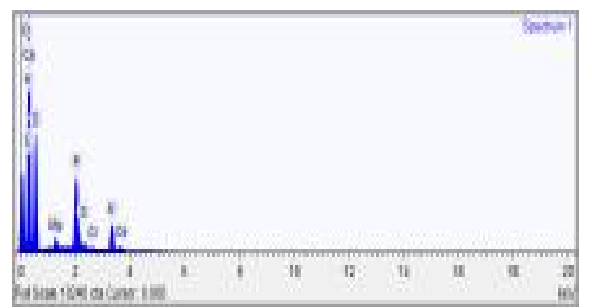

Fig. 4 Semi-quantitative energy spectrum of phosphorus-accumulating ability of Phosphorus accumulating organism

Table 1 semi quantitative determination of phosphorus
accumulating capacity of Phosphorus accumulating
organism accumulating bacteria
\begin{tabular}{|l|l|l|l|}
\hline Element & Weight \% & Weight $\% \sigma$ & Atomic \% \\
\hline Carbon & 54.966 & 0.480 & 63.959 \\
\hline Oxygen & 37.660 & 0.425 & 32.898 \\
\hline Magnesium & 0.453 & 0.022 & 0.261 \\
\hline Phosphorus & 4.098 & 0.060 & 1.849 \\
\hline Sulfur & 0.286 & 0.021 & 0.125 \\
\hline Chlorine & 0.091 & 0.018 & 0.036 \\
\hline Potassium & 2.301 & 0.042 & 0.822 \\
\hline Calcium & 0.145 & 0.022 & 0.051 \\
\hline
\end{tabular}

In order to further understand the surface morphology and composition of Phosphorus accumulating fungi Penicillium sp.JB201015 strain, the hyphae and polymer of polyphosphate and phosphorus release were spectrally scanned and analyzed by energy spectrum. The results show that in the simulated waste water, a large amount of phosphorus storage components (Figure 2 left) is formed in the bacteria. In combination with Fig. 4 and Table 1, it can be seen that the polymer formed by the strain of Penicillium sp. JB201015 is mainly composed of carbon, Oxygen,phosphorus, magnesium, potassium, accounting for $99.025 \%$ of the total mass, phosphorus content of the total atomic weight of $1.89 \%, 4.1 \%$ of the quality, in addition, also contains $\mathrm{S}, \mathrm{Cl}, \mathrm{Ca}$ and other elements. see Table 1.

\subsection{Effects of Carbon Source Types on Phosphorus Accumulation Ability of Strains}

In order to determine the effect of different carbon sources on the ability of Phosphorus accumulating organism, the effects of organic acid salts and carbohydrates on dry weight and phosphorus uptake were studied. The results sh owed that the dry weight and the amount of phosphorus were significantly higher than that of the carbohydrate (Table 2) when the organic acid salt was carbon source, which was consistent with the previously reported Phosphorus accumulating organism with volatile fatty acid molecules such as acetic acid, propionic acid Consistency for energy synthesis of phosphorus accumulation organism (Seviour et al, 2003).

Table 2 Effects of different carbon sources on the phosphorus accumulation ability of the strain

\begin{tabular}{llllll}
\hline & Glucose & Maltose & Fructose & Sodium Propionate & Sodium Acetate \\
\hline Dry Cell Weight $(\mathrm{g})$ & 1.09 & 1.02 & 0.87 & 1.15 & 1.28 \\
P.Accumulation $\left(\mathrm{mg} \cdot \mathrm{L}^{-1}\right)$ & 16.02 & 14.28 & 14.09 & 17.76 & 18.04 \\
\hline
\end{tabular}




\section{Effects of Nitrogen Sources on Phosphorus Accumulation Ability of Strains}

Nitrogen source is one of the important nutrient sources of microorganisms, and various forms of nitrogen are also important factors that cause eutrophication of water. The results show that the difference of dry weight and phosphorus Not much, ammonium salt slightly better than nitrate (Table 3).

\begin{tabular}{llllll}
\multicolumn{5}{c}{ Table 3 Effects of different nitrogen sources on the polyphosphate capacity of the strain } \\
\hline & $\left(\mathrm{NH}_{4}\right)_{2} \mathrm{SO}_{4}$ & $\mathrm{NH}_{4} \mathrm{NO}_{3}$ & $\mathrm{KNO}_{3}$ & $\mathrm{NaNO}_{3}$ & Peptone \\
\hline Dry Cell Weight $\left(\mathrm{g} \cdot \mathrm{L}^{-1}\right)$ & 12.5 & 13.6 & 11.8 & 11.2 & 9.4 \\
P. Accumuation $\left(\mathrm{mg} \cdot \mathrm{L}^{-1}\right)$ & 16.46 & 16.88 & 15.46 & 15.16 & 12.08 \\
\hline
\end{tabular}

Effects of different forms of phosphorus on phosphorus accumulation in phosphate fungi

In this paper, we studied the relationship between inorganic phosphorus and phosphorus uptake by Penicillium sp. JB201015 strain, which was the only phosphorus source in different forms of inorganic phosphate phosphate and phosphate rock. The results showed that although the strain JB201015 could use a variety of inorganic phosphorus as phosphorus source, the effect of different forms of inorganic phosphorus on the strain was different. Among them, the effect of calcium and phosphorus was the highest, and the dry weight of strain was reached after 10 days $1.43 \mathrm{~g}$, and the amount of phosphorus reached $88.98 \mathrm{mg} \cdot \mathrm{L}^{-1}$. In addition, the results also showed that the use capacity of strain JB201015 for different forms of inorganic phosphorus was related to the amount of phosphorus (Table 4).

Table 4 utilization of different forms of phosphorus by strains

\begin{tabular}{lllll}
\hline Phosphorous Source & $\mathrm{Ca}_{3}\left(\mathrm{PO}_{4}\right)_{2}$ & $\mathrm{AlPO}_{4}$ & $\mathrm{FePO}_{4}$ & Phosphate Powder \\
\hline Dry Cell Weight $\left(\mathrm{g} \cdot \mathrm{L}^{-1}\right)$ & 14.3 & 9.4 & 9.2 & 11.2 \\
P.Accumulation $\left(\mathrm{mg} \cdot \mathrm{L}^{-1}\right)$ & 88.98 & 42.17 & 52.39 & 38.86 \\
\hline
\end{tabular}

\section{Conclusion}

(1) Penicillium sp. JB201015 strain has typical characteristics of polyphosphate bacteria, the amount of phosphorus up to $84 \%$, phosphorus up to $88.98 \mathrm{mg} / \mathrm{L}$. Is a highly efficient polyphosphate strain.

(2) Polymorphic fungi Penicillium sp. JB201015 strains mainly composed of carbon, oxygen, phosphorus, magnesium, potassium, accounting for $99.025 \%$ of the total mass, phosphorus content of the total atomic weight of $1.89 \%$.

(3) The best carbon sources of Penicillium sp. JB201015 were organic acids, different organic nitrogen and inorganic nitrogen had no effect on cell growth and phosphorus accumulation, but different forms of inorganic phosphorus not only affected the growth of bacteria, but also Affect the amount of phosphorus.

\section{Acknowledgments:}

This work was financially supported by National Basic Research Program of China(2009CB426308).National applying Research Program of China(2012GB2 B100112) major scientific and technological research Program of Jilin provincial science and technology department(20130204041NY;20160204006YY)

\section{References}

[1]Shigaki F,Sharpley AN,Prochnow LI:Science of Agriculture,Vol.63(2) : 194-209(2006).

[2]Hao Xiaodi, Dai Ji, Hu Yuansheng, et al. Environmental science, Vol.29 (11): 3098-3103(2008).

[3]Cordell D,Drangert J O,White S. Global Environmental Change,Vol.19(2):292-305(2009).

[4]Li,C., Yang,J,Wang,X.,Wang,E,Li,B,He,R.'and Yuan, H. Bioresour. Technol. Vol.182,1825(2015).

[5]Mino, T. Biochemistry-Moscow Vol.65,341-348(2000).

[6]Zhu Wen,Wang Xin, Yang Yan Liu:Journal of environmental engineering( 2016). 
[7]Ge Yanhui, Zhao Lin, Zhou Yan.:environmental science and technology,Vol.1932 (2): 16(2014).

[8]Fuhs G W,Chen M: Microbial Ecology,Vol.2(2) : 119-138(1975).

[9]Shi Tingyu, Wang Huailin, Xie Jianping:Advances in Physiological Sciences, 42 (3): 181187(2011). 